\title{
UTILIZATION OF ORANGE WASTES FOR PRODUCTION OF VALUE ADDED PRODUCTS
}

\author{
MASOUD, M. R. M., FATMA H. EL MASRY, LOBNA A. HAREEDY \\ Horticultural Crops Tech. Res. dept, Food Tech. Res. Ins., ARC, Giza, Egypt.
}

(Manuscript received 1 st November 2016)

\begin{abstract}
I $\mathrm{t}$ is well known that orange is the most commonly and popular fruit grown not only in Egypt but allover the world. $75 \%$ of the total production of orange are consumed at the fresh form meanwhile $25 \%$ are utilized in production of different manufactured forms such as juices, concentrates, and jam. It is also established that the wastes remained after manufacture are $10-15 \%$ of the total production. Those wastes in case of being left without any utilization are considered to be very bad source for pollution, insects, and rats especially when they were inside the factories without removal. The wastes include seeds, fibers, and peels. Thus, it was logic and naturally to study the possibility of utilization of those wastes in producing new products. Thus, this study aims to investigate the possibility of utilization of those wastes in producing important products particularly. They were found to possess significant nutrients. In the current research, osmotic dehydration of orange peel using sucrose solution at mild temperature $\left(35^{\circ} \mathrm{C}\right)$ was investigated. Sucrose solution $(40,50$ and $60 \% \mathrm{w} / \mathrm{w})$ were employed for osmotic dehydration process. Responses of weight reduction (WR), solid gain (SG), water loss $(\mathrm{WL})$, color ( $\mathrm{L}^{*}, \mathrm{a}^{*}$ and $\left.\mathrm{b}^{*}\right)$ and texture (hardness) and sensory analysis were evaluated. It was found that sucrose concentration significantly $(p<0.05)$ affected the mass transfer terms during osmosis process. Moisture continent was decreased from $33.64 \%$ in fresh peel to be $16.25 \%$ on osmotic dried peels. The obtained results revealed an increase in yellowness $\left(b^{*}\right)$, decrease in lightness $\left(L^{*}\right)$ and redness $\left(a^{*}\right)$ as the sucrose concentration increased. Furthermore, osmotic ally dehydrated samples were considerably softer than untreated samples. Also increasing of sucrose concentration and dehydration time gave softer tissue of dehydrated product compared with the fresh orange peel.
\end{abstract}

Keywords: Orange peel, Osmotic dehydration, color measurements, weight reduction (WR), solid gain (SG), water loss $(\mathrm{WL})$, sensory evaluation.

\section{INTRODUCTION}

In Egypt the annual production of oranges is estimated at 750,350 tons. The peel of oranges are traditionally not used at industrial scales unless small amount are used for jam processing and orange oil production

Osmotic dehydration (OD) is one of most important complementary treatment and food preservation technique in the processing of dehydrated foods, since it has some benefits such as reducing the damage of heat to the flavor, color, inhibiting the 
browning of enzymes and decrease the energy costs (Alakali et al., 2006; Torres et al., 2006). Osmotic dehydration results in increased shelf-life, little bit loss of aroma in dried and semidried food stuffs, lessening the load of freezing and to freeze the food without causing unsignificant changes in texture (Petrotos and Lazarides, 2001). It has been reported that osmotic dehydration reduced up to $50 \%$ weight of fresh vegetables and fruits (Rastogi and Raghavararo, 1997).

Osmotic dehydration involves the immersion of foods (fish, vegetables, fruits and meat) in osmotic solution such as salts, alcohols, starch solutions and concentrated sugars, which some extent to dehydrates the food (Erle and Schubert, 2001). Different types of solutes such as fructose, corn syrup, glucose, sodium chloride and sucrose are used as osmotic agent for OD (Azuara and Beristain, 2002). Low molar mass saccharides (sucrose, glucose and fructose) make easy the sugar uptake due to high diffusion of molecules. It has proved to be a valuable quality method to get modestly processed fruits. Due to the much sensory resemblance between the natural and dehydrated products (Sousa et al., 2003).In recent years, osmotic dehydration has been widely utilized for fruits and vegetables preservation due to its potential to keep sensory and nutritional properties similar to fresh fruits and vegetables (Panades et al., 2008). Osmotic dehydration is process of immersing cellular materials into a concentrated solution for partial removal of water while increasing soluble solid content (Corzo and Bracho, 2005). The mass transfer rate depends on some factors like temperature, solution concentration, immersion time, size and geometry of sample and amount of sample to solution ratio). (Haj Najafi et al., 2014).

The present study aims at modeling the influence of the temperature, processing time, sugar concentration fix changes in mass of the orange peels and to determine the optimal conditions of temperature, processing time, for the water loss and solid gain in orange peel during osmotic dehydration.

\section{MATERIALS AND METHODS}

\section{Materials}

Orange peels were obtained from El Marowa Company for juice concentrate 6th of October industrial city Giza, Egypt. Orange peels were washed, and then cut into $0.5 \pm 0.1 \mathrm{~cm}$ cubes manually using sharp stainless steel knife.

\section{Methods}

\section{Osmotic dehydration procedure}

Osmotic solution was prepared using commercial grade sucrose and distilled water. The solution concentrations $(40 \%, 50 \%$, and $60 \% \mathrm{w} / \mathrm{w})$ throughout each experiment were monitored by refract meter (Atago-Master-20M, Japan). Experiments were performed at $35 \pm 0.5^{\circ} \mathrm{C}$ using an agitated water bath (Memmert, WNE14. 
Memmert GmbH Co. KG, Germany). Orange peels were soaked then drained and dried on oven. Sampling was performed in time intervals of zero, and 15, 30, 45, 60, 75, 90, 105 and 120min. All experiments were dried in air circulated oven (Tray type Fisher Scientific, Ser. No.253855T) at $70{ }^{\circ} \mathrm{C}$ for 2 hrs. and then reduces the temperature to $55^{\circ} \mathrm{C}$ till dryness. The first part of Osmotic dehydrated orange peel samples were soaked in sugar solution with different concentrates, the second part were soaked in orange juice and then backed in glass bottles at room Temperature for three months.

\section{Physico-Chemical analysis-:}

Samples were chemically analyzed for moisture, B. carotein,Total pectin,ash, minerals and crude fiber content according to the methods described by (AOAC 2010). Total Carbohydrates content were calculated by difference.

\section{Determination of weight reduction, solid gain and water loss}

The fresh and dehydrated orange peel after each contact times were placed in oven (Heraeus Vacutherm VT6025, Germany) at $105^{\circ} \mathrm{C}$ until constant weight (24 h) in order to measure the moisture and solids content according to Association of Official Analytical Chemists (AOAC) method 931.04 (AOAC, 1990).From these data, weight reduction (WR), solid gain (SG) and water loss (WL) were determined in all the cases at different times, $\mathrm{t}$, in agreement with the following equations (Panagiotou et al., 1999).

$$
\begin{aligned}
& \mathrm{WR}=\frac{\mathrm{M}_{0}-\mathrm{M}}{\mathrm{M}_{0}}, \\
& \mathrm{SG}=\frac{\mathrm{m}-\mathrm{m}_{0}}{\mathrm{M}_{0}}, \\
& \mathrm{WL}=\frac{(1)}{(2)},
\end{aligned}
$$

Where M0 is the initial mass of fresh sample $(\mathrm{g}), \mathrm{M}$ is the mass of sample after time $(\mathrm{t})$ of osmotic dehydration $(\mathrm{g}), \mathrm{m}$ is the dry mass of sample $(\mathrm{g})$ after time $(\mathrm{t})$ of osmotic dehydration, M0 is the initial dry mass of sample $(\mathrm{g})$.

\section{Color measurement}

Color analysis was carried out using a Minolta CR-300 portable colorimeter (illuminant $D$ 65) in terms of L* (lightness), a* (redness or greenness) and b* (blueness or yellowness) as an average of three measurements at three different locations. CIE-L*a*b* coordinates were obtained using D65 illuminant.

\section{Texture measurement}

Texture measurement of osmotic dehydrated cubes of orange peelwas performed using a universal test machine (TA.XT.PLUS Stable Micro Systems Ltd, 
Godalming, UK) with a $30 \mathrm{~N}$ load cell and an aluminum probe of $50 \mathrm{~mm}$ diameter at room temperature of $25^{\circ} \mathrm{C}$.

\section{Sensory evaluation :}

Sensory evaluation of processed orange peels were conducted by more than ten panelists (chosen by random) in the food technology research institute, according to the method of (Lindley, et al., 1993). Sensory attributes (color, taste, odor, crispiness, texture, freshness and overall palatability) of the studied orange peels were evaluated directly after preparation.

\section{Statistical Analysis}

The results were analyzed by analysis of variance (ANOVA) using the procedure by statistical analysis system (SAS) program according to Significant differences was determined at the level $P \geq 0.05$.

\section{RESULTS AND DISCUSSION}

\section{1- Sensory evaluation of dried orange peels at different sucrose concentration}

Sensory evaluation is one aspect considered to be of great importance since consumer acceptance usually encourages the marketing process of any new product. Sensory evaluation of processed orange peel which prepared with different sucrose concentration 40, 50 and 60\% were sensory evaluated for (color, taste, odor, texture, freshness and overall palatability), and the data was presented in Table (1). From this evaluation, we noticed that the sucrose concentration $60 \%$ have the best palatability then concentration $50 \%$. And the last score was for $40 \%$

Table 1. Sensory evaluation of osmotic dried orange peels at different sucrose concentration

\begin{tabular}{|c|c|c|c|c|}
\hline \multirow{2}{*}{ Principle } & \multicolumn{4}{|c|}{ Sugar concentrations } \\
\hline & $40 \%$ & $50 \%$ & $60 \%$ & LSD 0.05 \\
\hline Color & $7.2 b \pm 0.34$ & $7.8 a b \pm 0.7$ & $8.5 a \pm 1.2$ & 0.42 \\
\hline Taste & $6.4 c \pm 0.87$ & $8.2 a b \pm 0.55$ & $8.3 a \pm 0.64$ & 0.54 \\
\hline Odor & $6.8 c \pm 0.93$ & $8.4 a \pm 0.78$ & $7.8 a b \pm 0.64$ & 0.83 \\
\hline Texture & $7.4 b \pm 1.11$ & $7.9 a b \pm 1.03$ & $8.4 a \pm 1.08$ & 0.77 \\
\hline Freshness & $6.4 b \pm 0.86$ & $7.7 a b \pm 0.64$ & $8.4 a \pm 0.87$ & 0.63 \\
\hline Overallpalatability & $6.8 c \pm 0.76$ & $7.9 b \pm 0.85$ & $8,4 a \pm 1.08$ & 0.82 \\
\hline
\end{tabular}

\section{2- Chemical compositionof fresh as well as osmotic dried orange peels}

Data presented in Table (2) show the chemical composition of fresh and osmotic dried orange peels. The moisture content of orange peels was 33.46 on fresh orange peel decreased to $16.25 \mathrm{gm}$. On dried orange peel, respectively. We can notice that 
the total carbohydrates increased from $26 \%$ on fresh to $59 \%$ on osmotic dried orange peels.

Table 2. Chemical composition of fresh and dried orange peel per $100 \mathrm{gm}$.

\begin{tabular}{|l|c|c|}
\hline \multicolumn{1}{|c|}{ Principle } & Fresh peel & Osmotic dried peel \\
\hline Carbohydrates & $26.0 \mathrm{~g}$ & $59 \mathrm{~g}$. \\
\hline Protein & $1.50 \mathrm{~g}$ & $1.3 \mathrm{~g}$. \\
\hline Total Fat & $0.20 \mathrm{~g}$ & $0.7 \mathrm{~g}$. \\
\hline Dietary Fiber & $14.60 \mathrm{~g}$ & $11.94 \mathrm{~g}$. \\
\hline Moisture & $33.64 \mathrm{~g}$. & $16.25 \mathrm{~g}$. \\
\hline Ash & $2.8 \mathrm{~g}$ & $3.2 \mathrm{~g}$ \\
\hline Vitamin C & $38 \mathrm{mg}$ & $23 \mathrm{mg}$. \\
\hline Vitamin A & $420 \mathrm{IU}$ & $412 \mathrm{IU}$ \\
\hline Calcium & $161 \mathrm{mg}$ & $186 \mathrm{mg}$. \\
\hline Iron & $0.80 \mathrm{mg}$ & $1.0 \mathrm{mg}$. \\
\hline Magnesium & $22 \mathrm{mg}$ & $35 \mathrm{mg}$. \\
\hline
\end{tabular}

\section{Effect of sucrose concentration on weight reduction, solid gain and water} loss:

Figures 1-3 show the weight reduction (WR), solid gain(SG) and water loss (WL) of orange peel during osmotic dehydration at different sucrose solution concentrations, respectively. Sucrose concentration had significant $(p<0.05)$ effect on the WR, SG and WL. The higher extent of mass transfer in terms of WR, SG and WL during osmotic dehydration of orange peel was achieved by using more concentrated osmotic solution. This can be attributed to the large osmotic driving force between the fruit and the surrounding hypertonic medium (Azoubel and Murr, 2004). This result corroborates those obtained by several research groups for osmotic dehydration of cantaloupe, mango slices, apricot and guava cubes (Ito et al., 2007; Ispir and Togrul, 2009; Ganjloo et al., 2011). These results indicate that some benefits in terms of faster WR and WL could be achieved by choosing a higher concentration of medium. However, a much greater SG is also observed (Azoubel and Murr,2004). This finding also confirmed that highly concentrated sucrose solution $(>60 \% \mathrm{w} / \mathrm{w})$ is a mass transfer rate limiting parameter during osmotic dehydration process. 


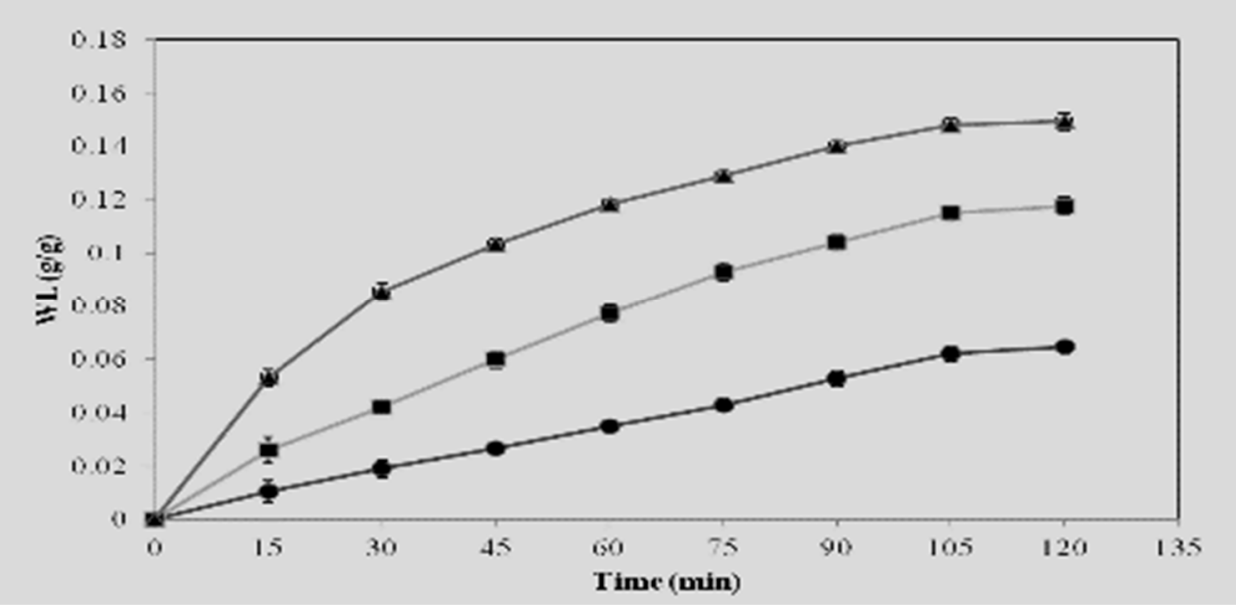

Fig.1. Weight reduction (WR) of orange peel duringosmotic dehydration using three different sucroseconcentrations (•) $40.0 \%(\mathrm{w} / \mathrm{w}) ;-(\quad) \quad 50.0 \%(\mathrm{w} / \mathrm{w})$; $(\Delta) 60.0 \%(\mathrm{w} / \mathrm{w})$ at mild temperature of $35^{\circ} \mathrm{C}$

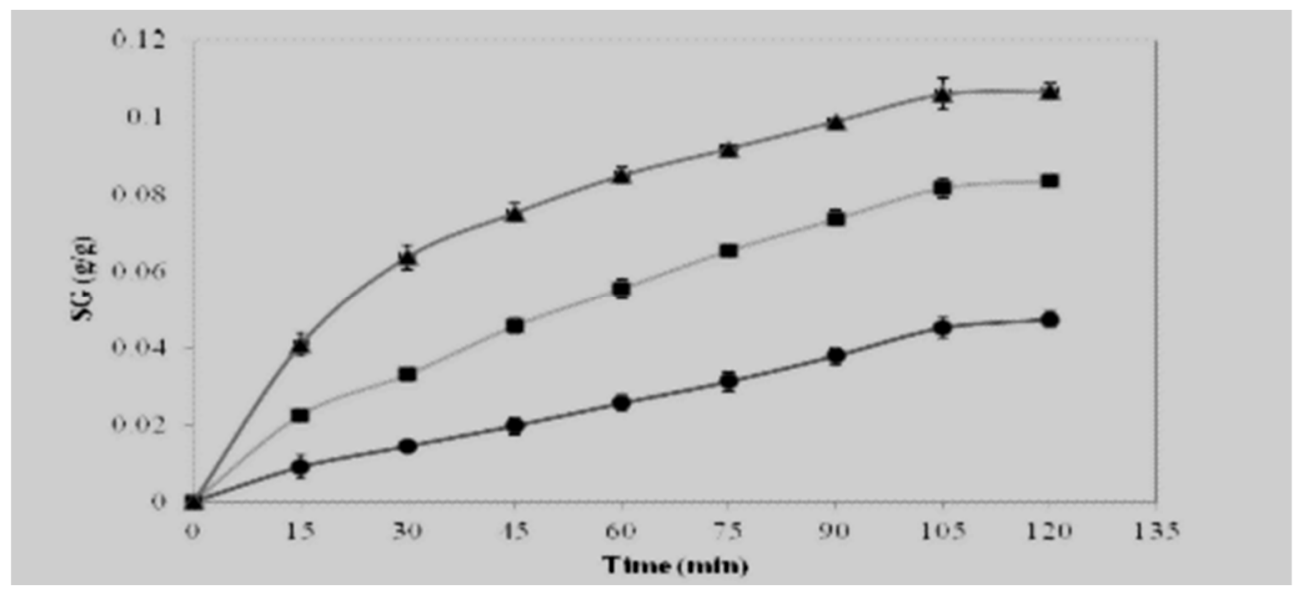

Fig.2. Water loss (WL) of orange peel during osmotic dehydration using three different sucrose concentrations ( $) 40.0 \%(\mathrm{w} / \mathrm{w}) ;(\quad) 50.0 \%(\mathrm{w} / \mathrm{w}) ;(\Delta) 60.0 \%$ $(\mathrm{w} / \mathrm{w})$ at mild temperature of $35^{\circ} \mathrm{C}$

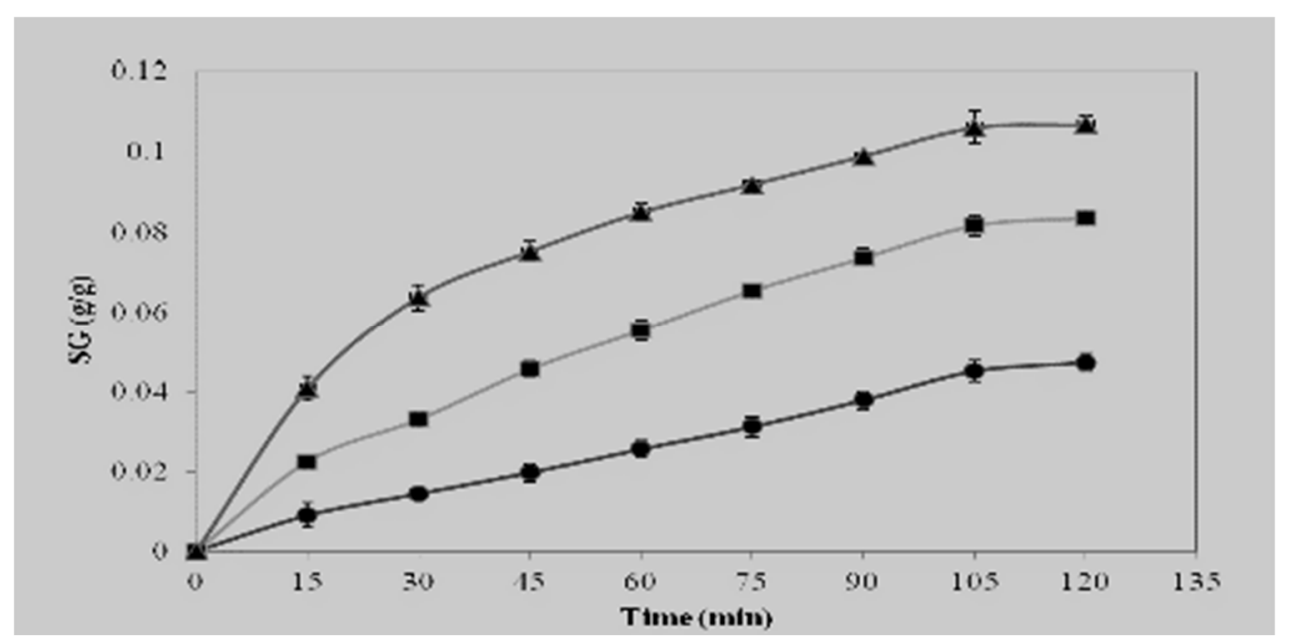

Fig.3. Solid gain (SG) of orange peel during osmotic dehydration using three different sucrose concentrations $(\bullet) 40.0 \%(\mathrm{w} / \mathrm{w}) ;(\boldsymbol{C}) 50.0 \%(\mathrm{w} / \mathrm{w}) ;(\boldsymbol{\Delta}) 60.0 \%$ $(\mathrm{w} / \mathrm{w})$ at mild temperature of $35^{\circ} \mathrm{C}$. 


\section{3- Changes in color parameters of orange peel:}

Color is one of the most important parameters affecting and indicating of palatability among different consumers at the point of purchasing food products. The color parameters of orange peel $s$ were measured after osmotic dehydration process.The Lightness $\left(L^{*}\right)$, redness $\left(a^{*}\right)$ and yellowness $\left(b^{*}\right)$ values of fresh orange peelwere $26.97 \pm 1.27,32.7 \pm 1.99$ and $5.5 \pm 0.4$, respectively. Typical plots of variation of color parameters with dehydration time at different sucrose concentrations and constanttemperature of $35^{\circ} \mathrm{C}$ were illustrated in tables 3-5. It was revealed that the $b^{*}$ value increase $(p<0.05)$ with increase in dehydration time and solutionconcentration, while both $L^{*}$ and $a *$ values decreased $(p<0.05)$.

Table 3. of $L^{*}$ value changes of orange peel using three different sucrose concentrations

\begin{tabular}{|l|c|c|c|}
\hline \multirow{2}{*}{ Dehydration Time (min) } & \multicolumn{3}{|c|}{ Sucrose concentration\% } \\
\cline { 2 - 4 } & 40 & 50 & 60 \\
\hline 0 & 28 & 28 & 28 \\
\hline 15 & 26.7 & 27.8 & 27 \\
\hline 30 & 27.4 & 27.6 & 26.8 \\
\hline 45 & 27.0 & 27.0 & 26 \\
\hline 60 & 26.5 & 26.0 & 25.0 \\
\hline 75 & 26 & 25.5 & 24.6 \\
\hline 90 & 25.5 & 25 & 24.3 \\
\hline 105 & 25.2 & 24.80 & 24.00 \\
\hline 120 & 25 & 24.20 & 23.60 \\
\hline
\end{tabular}

Table 4. of a* value changes of orange peel using three different sucrose concentrations

\begin{tabular}{|l|l|l|l|}
\hline \multirow{2}{*}{ Dehydration Time (min) } & \multicolumn{3}{|c|}{ Sucrose concentration\% } \\
\cline { 2 - 4 } & 40 & 50 & 60 \\
\hline 0 & 32 & 32 & 32 \\
\hline 15 & 30 & 29 & 27 \\
\hline 30 & 29 & 27 & 26 \\
\hline 45 & 28 & 26 & 25 \\
\hline 60 & 28 & 25 & 23 \\
\hline 75 & 27 & 24 & 22 \\
\hline 90 & 27 & 24 & 20 \\
\hline 105 & 26 & 23 & 19 \\
\hline 120 & 26 & 22 & 18 \\
\hline
\end{tabular}

Table 5. of $b^{*}$ value changes of orange peel using three different sucrose concentrations

\begin{tabular}{|l|c|c|c|}
\hline \multirow{2}{*}{ Dehydration Time (min) } & \multicolumn{3}{|c|}{ Sucrose concentration\% } \\
\cline { 2 - 4 } & 40 & 50 & 60 \\
\hline 0 & 3.8 & 3.8 & 3.8 \\
\hline 15 & 3.8 & 3.8 & 3.8 \\
\hline 30 & 4.2 & 4.6 & 4.8 \\
\hline 45 & 4.4 & 4.9 & 5.3 \\
\hline 60 & 4.6 & 5.2 & 5.8 \\
\hline 75 & 4.8 & 5.7 & 6.2 \\
\hline 90 & 5.1 & 5.8 & 6.7 \\
\hline 105 & 5.5 & 6.1 & 7.1 \\
\hline 120 & 5.8 & 6.2 & 7.4 \\
\hline
\end{tabular}




\section{Changes in hardness of orange peel}

The variations of hardness during osmotic dehydration of orange peels using different sucrose concentrations were presented in Figure 4. It is clear that osmosed samples were considerably softer than untreated samples and as sucrose concentration and time increased the hardness of the samples decreased gradually. This was explained by substantial changes in cellular tissues. Similar observations were reported by Lewicki and Lukaszuk (2000), Katsiferis et al. (2008) and Castello et al. (2010) working on apples, orange, Granny Smith apple slices and strawberries.

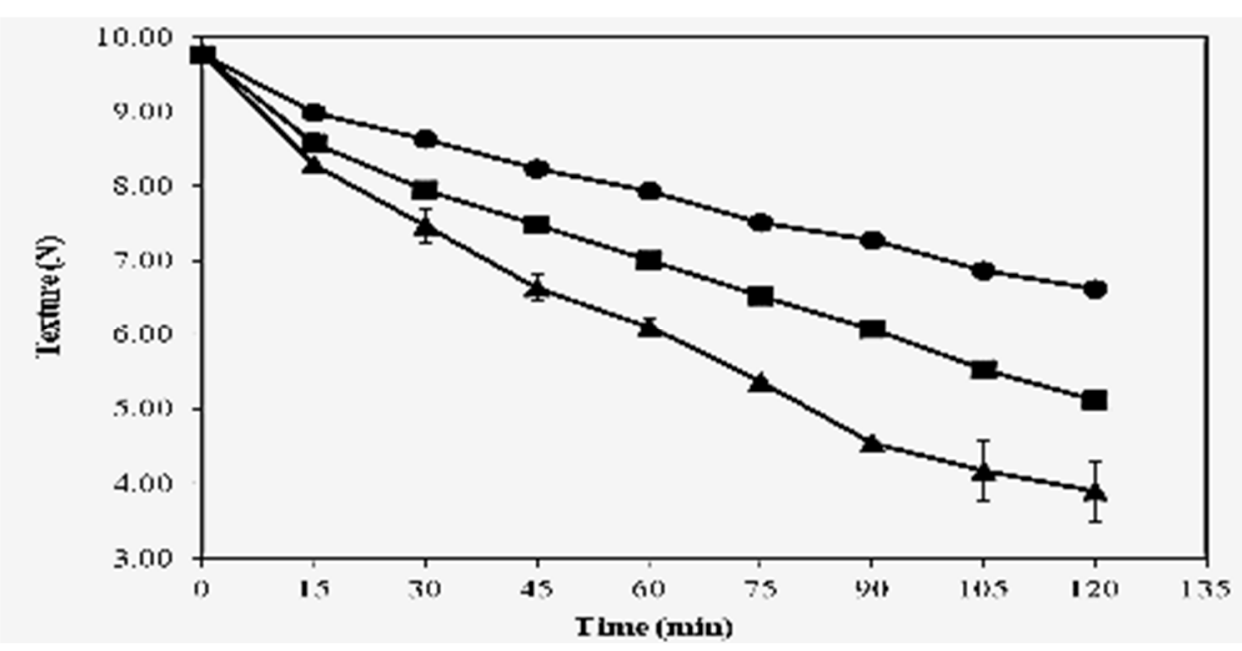

Fig.4. Hardness value changes of orange peel using three different sucrose concentrations $(\bullet)$ 40.0\% (w/w); ( ) $50.0 \%(\mathrm{w} / \mathrm{w}) ;(\Delta) 60.0 \%(\mathrm{w} / \mathrm{w})$ at mild temperature of $35^{\circ} \mathrm{C}$

\section{CONCLUSION}

In current research, the effects of sucrose concentrations on mass transfer in terms of WR, WL and SG were investigated during osmotic dehydration of orange peel. It was revealed that the higher values of solution concentration resulted in higher flows of water and solids and loss of weight through the orange peel cubes. Tristimuluscalorimetry and texture analysis made it possible to perform a qualitative analysis during the osmotic process performed under different solution concentrations. It was showed that an increase in yellowness ( $\left.b^{*}\right)$ coordinate and $a^{*}$ decrease in lightness $\left(\mathrm{L}^{*}\right)$ and redness $\left(\mathrm{a}^{*}\right)$ was achieved as the sucrose concentration increased. Thiscould be attributed to the shrinkage of plant tissue which leads to increase in samples opacity, alteration of fruit pigments and solids uptake. It was found that osmosed samples were considerably softer than untreated samples. As the concentration of the osmosed samples increase, the hardness decrease which led to 
produce softer product texture. Finally it could be clearly concluded through that aforementioned study that it is successful, practicable and economic to utilize orange wastes in producing valuable added products by asmotic dehydration. This will lead to make well use of orange peels remained after orange processing to different products in producing valuable added products instead of being left inside factories causing contamination as well as seets, rats and microorganisms reproduction.

\section{REFERENCES}

1. Alakali, J.S., C.C. Ariahu and N.N. Nkpa. 2006.Kinetics of osmotic dehydration of mango. Journalof Food Processing and Preservation.30:597-607.

2. AOAC. 2010. Official methods of analysis. Washington: Association of Official Analytical Chemists.

3. Azoubel, P. M. and Murr, F. E. X. 2004. Mass transfer kinetics of osmotic dehydration of cherry tomato. Journal of Food Engineering 61, 291-295.

4. Azura, E and C.I. Beristai. 2002. Osmotic dehydration of apples by immersion in concentrated sucrose / matlodextrin solution. Journal of Food Processing hesewation. 26: 295306.

5. Castelló, M. L., Fito, P. J. and Chiralt, A. 2010. Changes in respiration rate and physical properties of strawberries due to osmotic dehydration and storage. Journal of Food Engineering 97: 64-71.

6. Corzo, O. and Bracho, N. 2005. Osmotic dehydration kinetics of sardine sheets using Zugarramurdi and Lupín model. Journal of Food Engineering 66, 51-56.

7. Erle, U. and H. Schubert. 2001. Combined osmotic and microwave-vacuum dehydration of apples and strawberries. Journal of Food Engineering. 49:193-199.

8. Ganjloo, A., Rahman, R.A., Bakar, J., Osman, A. and Bimakr, M. 2011. Kinetics Modeling of Mass Transfer Using Peleg's Equation During Osmotic Dehydration of Seedless Guava (PsidiumguajavaL.): Effect of Process Parameters. Food and Bioprocess Technology 5: 2151-2159.

9. Haj Najafi, A., Yusof, Y. A., Rahman, R. A., Ganjloo, A. and 1Ling, C. N. 2014. Effect of osmotic dehydration process using sucrose solution at mild temperature on mass transfer and quality attributes of red pitaya (Hylocereuspolyrhizusis). International Food Research Journal 21(2): 625-630 (2014)

10. Ispir, A. and Togrul, I. T. 2009. Osmotic dehydration of apricot: Kinetics and the effect of process parameters. Chemical Engineering Research and Design 87, 166180. 
11. Ito, A. P., Tonon, R. V., Park, K. J. and Hubinger, M. D. 2007. Influence of process conditions on the mass transfer kinetics of pulsed vacuum osmotically dehydrated mango slices. Drying Technology 25 (11), 1769-1777.

12. Katsiferis, T., Zogzas, N. and Karathanos, V. T. 2008. Mechanical properties and structure of unripe oranges during processing of spoon sweets. Journal of Food Engineering 89: 149-155.

13. Lewicki, P. P. and Lukaszuk, A. 2000. Effect of osmotic dewatering on rheological properties of apple subjected to convective drying. Journal of Food Engineering 45(3): 119-126.

14. Lindley, M.G.; Beyts, P.K.; Canales and Borrego,(1993). Flavor modifying characteristics of the intense sweetener meohesperidindihyrochalcone. J. Food Sci. 58:592-598.

15. Panades, G., Castro, D., Chiralt, A., Fito, P., Nuñez, M. and Jimenez, R. 2008. Mass transfer mechanisms occurring in osmotic dehydration of guava. Journal of Food Engineering 87(3): 386-390.

16. Panagiotou, N. M., Karathanos, V. T. and Maroulis, Z. B. 1999. Effect of osmotic agent on osmotic dehydration of fruits. Drying Technology 17: 175-189.

17. Petrotos, K.B. and H.N. Lazarides. 2001. Osmotic concentration of liquid foods. Journal of Food Engineering. 49:201-206.

18. Rastogi, NK and K. Raghavarao. 1997. Water and solute diffusion coefficients of carrot as a function of temperature and concentration during osmotic dehydration. Journal of Food Engineering. 34:429440.

19. Sousa, P.H.M., M.A. Souza Neto, G.A. Maia، M.S.M. Souza Filho and R.W. Figueiredo. 2003.Desidrataçãoosmótica de frutos. Boletim da SociedadeBrasileira de Ciência e Tecnologia de Alimentos. 37: 94-100.

20. Torres, J.D., P. Talens and I.A Escriche. 2006. Influence of process conditions onmechanical properties of osmotically dehydratedmango. Journal of Food Engineering.74: 240-246. 


\section{الاستفادة من مخلفات البرتقال فى انتاج منتجات ذات قيمة مضافة}

محمد رمضان محمد مسعود، فاطمة حسن المصري، لبني عبد الفتاح هريدي

قسم بحوث تكنولوجيا الحاصلات البستانية. معرد بحوث تكنولوجيا الاغذية. مركز البحوث الزراعبة

يعتبر البرتقال من اهم الفاكهة التي تتمو ليس فى مصر وحسب بل فى العالم. وقد اجريت

هذة الدر اسة للاستفادة من مخلف قثور البرتقال لانتاج منتجات ذات قيمة اقتصادية مثل الاستفادة من لن لهن

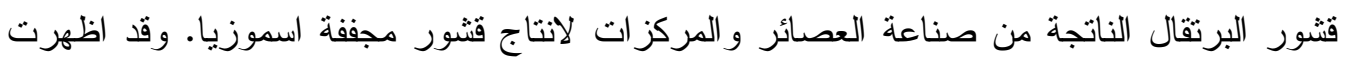

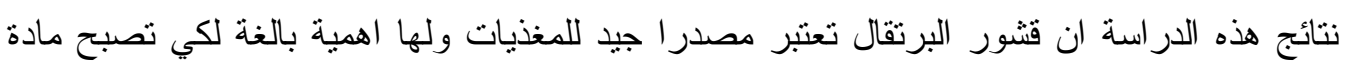
اولية فى الكثير من الصناعات

تم فى هذه البحث تجفيف قثور البرتقال باستخدام طريقة التجفيف الاسموزي باستخدام

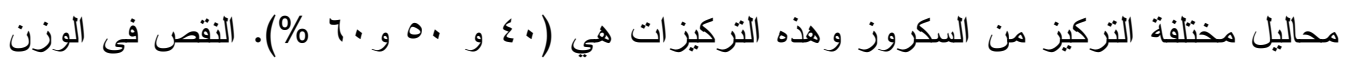

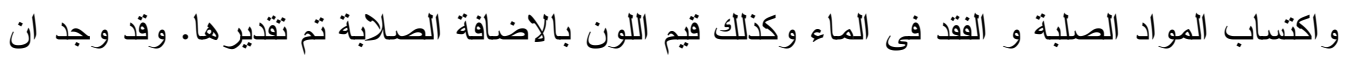
تركيز السكروز يؤثر على خصائص انتقال الكتلة اثناء خطو ات الاسموزية. الكربو هيدرات و الالياف

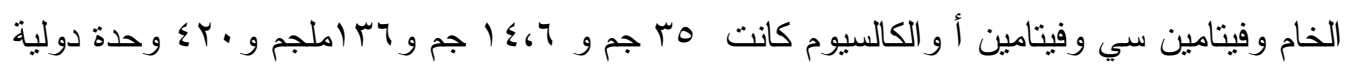

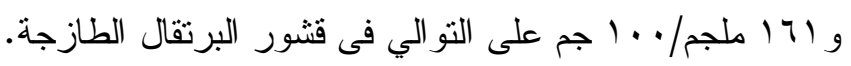

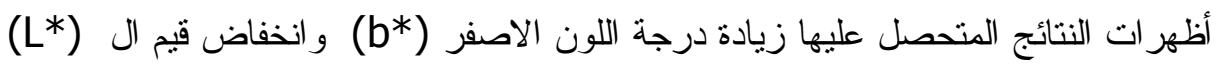

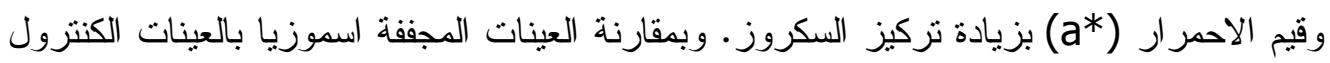

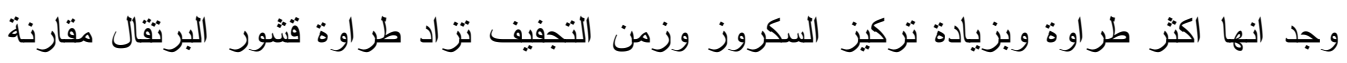
القشور الطازجة. لذا فقد ثبت من خلال هذه الدراسة انه من الممكن عمليا" و اقتصاديا" الاستفادة من قشور

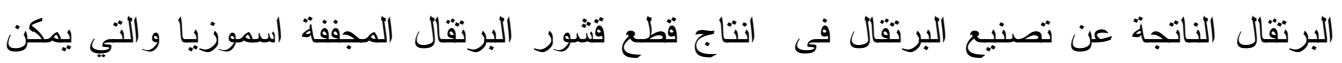

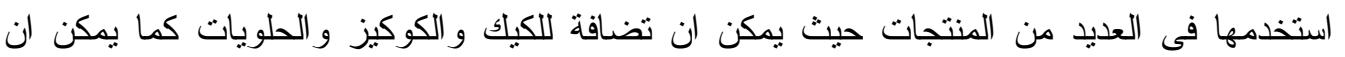
تنتخدم كبديل للزبيب وكذلك يمكن اضافة تلك القطع الى عصير البرتقال لتحسين الطعم (عصير برتقال بالقطع) كمنتج جديد. وختاماً يعتبر هذا البحث محاولة للاستفادة من مخلفات تصنيع ثمار البرتقال منل القشور

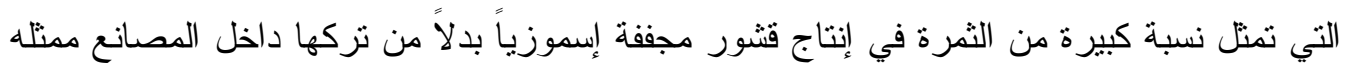
مصدر اً خطير اً للنلوث وتكاثز الحشر ات و الفئر ان و الكائنات الحية الدقيقة. 